\title{
Budgets and Performance of Research Projects in Public Universities in the Coastal Region, Kenya
}

\author{
Hamisi Jitta Mwaguni, John Mbugua, and Charles Rambo
}

\begin{abstract}
The purpose of the study was to assess how budgets influences performance of research projects of public universities in Coast region, Kenya. The study used a pragmatism paradigm. A descriptive survey and correlation research design were adopted. A targeted population of 1110 academic and non-academic employees for the two universities were used for this study. A sample of 285; consisting of 173 from Technical University of Mombasa and 112 from Pwani University was employed through proportionate and simple random sampling to obtain a representative sample. Primary data collection was done by use of interview guide and open and close ended questionnaires. A pilot test was conducted at University of Nairobi main campus as it would provide a representation of the study to test data collections tools reliability and validity. Data analysis was by inferential and descriptive statistics; mean, frequencies, percentages and standard deviation. Shapiro-Wilk Test was employed to establish whether data was normally distributed or not and adjustments were made to make the data normal. Durbin Watson method was also used to test autocorrelation of the variables. The findings established that budget influences performance of research projects with a composite mean of 3.93 and standard deviation of 0.747 . Budget had a positive strong correlation at 0.89 . The data also established a positive relationship amongst budget on performance of research projects in public universities. Further studies can be done on other monitoring and evaluation tools to ascertain which is most appropriate for monitoring and evaluation tool. Further studies should be conducted in other parastatals.
\end{abstract}

Index Terms-Budget, Performance Contracting, Performance, Research Projects, Key Informant Interview.

\section{INTRODUCTION}

Performance in public universities in Africa and much of the developing world has been declining in the past due to limited government finance, support and lack of some sort of reward for the academic staff. This scenario has led to brain-drain, occasioned by migration of professionals to Europe in pursuit of improved remuneration and compensation that are not offered in African countries. African universities have achieved significant accomplishments in maintaining their staff complements (Saint, 2002). Remuneration is generally poor due to their non-competitive purchasing power as major source of academic staff dissatisfaction (Blair and Jordan, 1994). Universities all over African are faced with a test of attracting and retaining competent staff (Amonoo-Neizer, 1998). African universities have been adversely affected by the brain-drain syndrome of good and greatly trained

Published on May 25, 2020.

Hamisi Jitta Mwaguni, Technical University of Mombasa, Kenya.

(corresponding e-mail: hmwaguni@gmail.com) specialists from the continent. Many African institutions of higher learning remain with young, lacking experience and inadequately qualified personnel.

As reported by the Economic Commission for Africa between the years 1960-1989 estimated that over 127,000 highly qualified African specialists have migrated in search of greener pastures (Olusola, 2007). The African continent has been losing a little over 20,000 professionals yearly since 1990s. The continuous depletion of skillful workforce contributes to increase gap in technology and science amongst other continents and Africa (Olusola, 2007). There is exodus of more scientists and engineers from African to the USA than in the entire. This outcome has left Africa reliant on foreign expatriates for a majority of the development projects as professionals seek greener pastures elsewhere. A budget is a tool used in monetary management which frequently formulates budget requests and performance plans that measures output, define performance goals and outcomes of various actions that are intended at attaining performance goals. This helps as plans set on an annual basis set forth in measurable monetary performance standards for every objective set within the financial year (Larson, 1999).

\section{A. Statement of the Problem}

Public and private institution of higher education are faced with challenges in growth and growth of curricula resulting from inadequate funding which has adversely affected performance of research projects in Kenyan Universities. The country's economic situation together with Government policies to cut public-sector spending but escalating guideline, present both a shortfall on student enrollment rates and a competitive market place. This has adversely affected performance of research projects in this sector as universities have resorted to concentrate more on teaching than research thus not following the set guidelines; (Universities Standards and Guidelines 2014 and Universities Act 2012). Funding in research has also dropped from $15 \%$ to $8 \%$ hence affecting performance of research projects in public universities.

\section{B. Purpose of the Study}

This study sort to assess how budgets influences performance of research projects in selected public universities in Coast region, Kenya.

\section{Objectives of the Study}

The study aims to accomplish the subsequent objectives:

i. To establish how reviewing budget influence performance of research projects in public universities.

ii. To determine how compliance with budgets 
influence performance of research projects in public universities.

iii. To assess how budget guidelines influence performance of research projects in public universities.

iv. To establish how controlling budgets influence performance of research projects in public universities.

$\mathbf{H}_{\mathbf{0}}$ : Budgets has no significant influence on performance of public universities.

\section{LITERATURE REVIEW}

Just like other government institutions, public universities operate in an environment dependent of the government. As a result of emancipation, uncertain economic changes, and new and existing regulations, public universities have been forced to go through changes to compete effectively and survive (GoK, 2005). This has consequently led to poor performance due to compromised quality of university education as competition amongst universities has soared. Most countries in Africa have gone through financial limitations owing to unpredictable changing economic conditions coupled with uncontrolled increase in population and delivery of social services to the populace. This has forced University education to compete with other sectors of the economy due to inadequate funds from government.

The following challenges have been found to adversely affect performance of research projects in Kenyan public universities; Low university funding by the; Lack/inadequate of research facilities; equipment and laboratories; Lack of qualified personnel; Universities growing too thin; lack of direction; Hastily mounting privately sponsored courses thus leading to overreliance on teaching; Poor linkages between industry and the University; hence undermining industry-university research funding; Poor intellectual property policies, plagiarism, lack of research ethos, poor access to information; Poor linkage of university research to nations vision; poor supervision, management, absence of monitoring and evaluation of university research projects; and low influence of university research and utilization of research findings at the national level (CUE, 2016).

As a policy, a budget helps to decide the way in which resources are managed (Premchand, 2000). The aim of budgeting is limited to expenditure on money, maximizing savings, and capping expenditures. Budget implementation requires advance course of action which progressed within the limits of the end of the means available and budget (Frucot and Shearon, 2001). Effective implementation of budgets is frequently evaluated by addressing variances between budgeted items and the actual performance (Horngren, 2000).

The two common techniques for budgeting are zero and incremental budgeting. An incremental budget is whereby statistics are based on actual spending for the preceding financial year with an additional calculation for inflation. It is time saving but at time provides inaccurate information. This technique is only appropriate for institutions which have similar terms of actions in the preceding years. However, limited dynamic institutions or tasks are so steady as to make this budgets work (Lucey, 2004). In zero budgeting is where historical data is not put into consideration as the process starts from the beginning of the financial year. Result of this is a comprehensive and precise budget. However, this approach is more tedious. This route is mostly used especially when institutions are new (Kariuki, 2010).

Modern budgeting support management of performance in organizations by incorporating known financial conclusions with regular re-forecasting by analysis of the trends without losing the control and accountability mechanism. An organizations reporting system on financial performance management will get several sources of information and reflect the series of departmental perspectives and stakeholder (MelekEker, 2007). Performance reporting can be developed through several approaches to development of performance metrics. Organizations cannot measure their organizations smart decisions or value for money about future priorities and resources without an integrated financial resources. Considerations should be made to encourage development of management reports for purposes of providing an allround picture of an organization through integrating operational and financial performance information. (Hansen and Mowen, 2005).

A good management report provides exhaustive information of what is presently ongoing and what is expected to transpire in the near future. These reports provide information that is key to making necessary corrections or necessary action. All areas need to be covered for the actions to cover the whole organization. This infers that financial data and operational are presented together in a form that is consistent and comparable (Kariuki, 2010). Other performance and risk aspects are documented along within financial reports. Risks are computed financially thus hindering doubt in financial forecasts. Some organizations find it supportive to present a frequently updated board-level for opportunities and risks report, where periodic forecast is the key financial ups and downs are displayed beside each periodic forecasts (Horngren, 2000).

A study by Otley and Pollanen (2000), showed that partaking in budget making, task and control vagueness negatively influences performance. But effects differ in scenarios where there is collective interaction of variables. The study established that budgetary control, participations, and task ambiguity have a negative effect on performance, in instances where budget control is high, participant's makes positive influence to performance. A single explanation for this rise in performance could be associated to bureaucratic justice, since budgetary control permits more participation in budgeting, as their view of procedural justice is positively influenced by budget control.

An examination on the relationship between effects of budget control on performance, using a representative of enormous cities in United States between the years 20032004. It scrutinized whether the tightness of budget controls or effective level of budget control within the towns as scaled by variance budgets contribute to measuring performance by rating bonds and established that active level of budget control is considerably associated to rating bond (Carolyn, 2007). 
A descriptive study on the elements that influence the implementation of budgets in Kenya universities, University of Nairobi, it established that there is inefficient procedure in the budget preparation and budgeting faces a myriad of problems. Further, it established that budgets are strong tool for planning (Gachithi, 2010).

Mbugua, (2013) studying a sample of 60 companies using a cross-sectional research design concluded that aspects of budgeting practices such as budget planning and participation in budgeting has a substantial positive effect on the revenue collection efficiency of water service providers while budget control practices and budgeting approach have no significant effect on revenue collection in the studied industry.

Investigations on evaluating the budget effects on performance of financial listed public service vehicle corporations in Kenya by Mwangi, (2014) highlighted that, vehicle companies that adoption of budgets had positive performance ratios and those that do not have budgets had negative performance ratios. It also exposed that most individuals in the industry were not conscious of budgeting procedures and even those who were aware did not effectively put them into use.

\section{A. Theoretical Framework}

This theory denotes that performance and motivation is higher when people set specific goals, which at times may be problematic but acceptable and there is constant response on how employees perform (Armstrong, 2005). Goal-setting theory proposes that employee evaluation is based on the attainment of set objectives or goals (Saleemi, 2006). The theory emphasizes workers should discuss the targets together with their line managers within a specified period of time (Saleemi, 2006). The harder the goals, the harder to attain them and this in term leads to higher performance and rewards once the goals have been attained. (Latham and Lock 2002). The harder the goals, the higher the performance as opposed to easy goals/targets (Latham and Locke, 2009).

For this study, a budget, is essential as staff set their goals and targets which have been negotiated and agreed upon by their line managers. Studies involving a variety of tasks have reliably found that performance positive related to goal setting (Latham and Locke, 2007). Contrary findings have been experienced when identifying performance dimensions by this theory has been accompanied by a set of difficulties regarding in what way these goals and dimensions will be equated (Mullin, 1999). Experiences from the Inland Revenue, suggested that there is no indication to show the relationship of how clearer goals helped have helped with employee motivation towards performing better particularly when employees felt like they were already over working. Determination is essential in setting challenging objectives which may be problematic when criticism is acknowledged to proposing that previously set goals were not achieved (William et. al., 2005).

\section{B. Conceptual Framework}

The conceptual framework, Fig. 1, shows the relationship between the independent, dependent variables and moderating variables.

\section{Independent Variable}

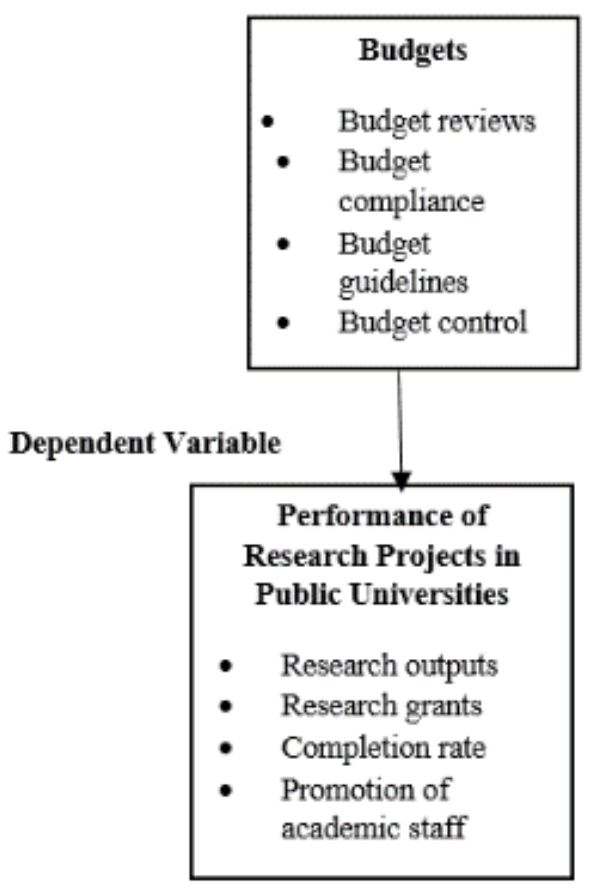

Fig. 1. Conceptual Framework

\section{Research Methodology}

This study adopted a pragmatism paradigm. Tashakkori and Teddlie (2003) recognize pragmatism as a paradigms offers a fundamental philosophical structure for mixed methods research. Pragmatist's emphasis is on knowledge creating through points of action to the types of "joint actions" or "projects" that dissimilar groups or people can achieve together (Morgan, 2007). Researchers are allowed to select the methods (or grouping of methods) that best suits responses to the research questions (B. Johnson \& Onwuegbuzie, 2004). This research used a descriptive correlation and survey research design which defines current the state of affairs. Orodho (2003) described a research design as a summary, plan or scheme used to generate solutions to research difficulties as well hypotheses testing. It can be viewed as a collection of conditions for gathering and analyzing data with an aim of combining its relevance with the purpose of research. Descriptive design is used when gathering information about individual's habits, sentiments, attitudes and other behaviors (Orodho and Kombo, 2003).

The size of the sample employed in this thesis was guided by Fishers formula (Fisher, Laing and Stroker, 2003). This aided in obtaining a paradigmatic sample from the target population. The target populace was 1110 drawn from the two universities. It was achieved by the formula given in the equation below.

$n=\frac{z^{2} p q}{d^{2}}$

$n=$ Anticipated size of sample (if the target population is larger than 10,000).

$z=$ Standard normal deviate at required levels confidence. 
$p=$ Proportion of the targeted population approximated features in the study. If it is unknown, then $0 \%$ will be used.

$q=1-0.32=0.68$.

$d=$ Statistical significance level set $=0.05$

$z=$ Assuming $(95 \%)$ confidence interval $\mathrm{Z}=1.96$

$n=\frac{1.96^{2} 0.5 * 0.5}{0.05^{2}}=384$

For a populace lesser than 10,000, modification will be prepared by Cochran's correction formula (Cochran, 2011);

$n f=\frac{n}{1(n / N)}$

Where;

$n f=$ Size of sample if populace is $<10,000$

$n=$ Population sample equal to 10,000 or more

$N=$ Population size from drawn sample

$n f=384 / 1(384 / 1110)$

$n f=285.31$ Therefore $n f=285$.

Therefore, the sample was 285 drawn from the target population of 1110 using fisher's formula of 2003.

The study used a proportionate and simple random sampling. This aided to attaining a representative sample. In random sampling, all sample size in the population gets the same chance to be chosen (Mugenda and Mugenda, 2003). This allowed generalization for a bigger populace with an error margin that can statistically be determined.

TABLE I: SAMPLING PROCEDURE

\begin{tabular}{llll}
\hline Category of staff & TUM & PU & Total \\
\hline Academic & 5 & 7 & 12 \\
Professors & 7 & 5 & 12 \\
Associate Professors Senior Lecturers & 5 & 12 & 17 \\
Lecturers & 32 & 18 & 50 \\
Tutorial Fellows & 18 & 15 & 33 \\
Administration & & & \\
Heads of Departments & 19 & 18 & 36 \\
Sections heads & 16 & 14 & 30 \\
Administrative Asst. & 32 & 10 & 42 \\
Technicians & 40 & 12 & 52 \\
\hline Total & $\mathbf{1 7 4}$ & $\mathbf{1 1 1}$ & $\mathbf{2 8 5}$ \\
\hline \hline
\end{tabular}

Therefore, the sample used for this study was 285 people from both universities from each category of staff. This method of establishing the size of the sample was used based on the strength of each category and to avoid biasness.

The tools adopted for collecting data were an open-ended questionnaire and interview guide. They were employed for data collection from the selected samples from both universities; Pwani University and Technical University of Mombasa. Data was analyzed by use of both descriptive and inferential statistics. Further, both qualitative and quantitative methodologies were applied to examine, process and interpret data.

$\mathbf{H}_{\mathbf{0}}$ : Budgets has no significant influence on performance of public universities

$Y=\beta_{0}+\beta_{2} X_{2}+\varepsilon_{2}$

Whereby;

$Y=$ Performance of research projects in public Universities

$\beta_{0}=$ Constant

$\beta_{2}=$ Coefficients of determination

$X_{2}=$ Budget process

$\varepsilon=$ Error term

\section{RESUlts}

The questionnaire return rate was $87.72 \%$, demographically, 57.7 were male while 42.3 were female. $12.5 \%$ had PhD's, 36.1\% had Masters, 25\% had Bachelors, $4.2 \%$ had Higher Diplomas, 20.8\% Diploma and 1.4\% Certificates. On length of service, $52.9 \%$ served for $6-10$ years, $28.6 \%$ served from $1-5$ years, $11.4 \% 11-15$ years and $7.1 \%$ above 15 years. The age of respondents ranged from $52.9 \%$ ranged between 30-39 years, 28.6\% 40-49 years, $11.4 \% 50-59$ years and $7.1 \%$ above 60 years.

\section{A. Budgets and Performance of Research Projects in Public Universities}

The objective was to establish how budgets influences performance of research projects in public universities. Therefore, the researcher enquired on the respondents' agreement or disagreement levels with the following proclamations on a likert scale of $1-5$ where $1=$ Strongly Disagree; 2= Disagree; Agree; 3= Neutral; 4=Agree; $5=$ Strongly Agree). The results are presented in Table II.

TABLE II: BUdGETS AND PERFORMANCE OF RESEARCH PROJECTS IN PUBLIC UNIVERSITIES

\begin{tabular}{|c|c|c|c|c|c|c|c|c|}
\hline S/No & Statements & $1 \%$ & $2 \%$ & $3 \%$ & $4 \%$ & $5 \%$ & M & S.D \\
\hline 1. & $\begin{array}{l}\text { Budget reviews influence performance of research projects in } \\
\text { public universities }\end{array}$ & $\begin{array}{l}7 \\
(2.8 \%)\end{array}$ & $\begin{array}{l}14 \\
(5.6 \%)\end{array}$ & $\begin{array}{l}49 \\
(19.7 \%)\end{array}$ & $\begin{array}{l}109 \\
(43.7 \%)\end{array}$ & $\begin{array}{l}71 \\
(28.2 \%)\end{array}$ & 3.89 & 0.871 \\
\hline 2. & $\begin{array}{l}\text { Compliance with budgets influence performance of research } \\
\text { projects in public universities }\end{array}$ & $\begin{array}{l}11 \\
(4.2 \%)\end{array}$ & $\begin{array}{l}17 \\
(6.9 \%)\end{array}$ & $\begin{array}{l}31 \\
(12.5 \%)\end{array}$ & $\begin{array}{l}118 \\
(47.2 \%)\end{array}$ & $\begin{array}{l}73 \\
(29.2 \%)\end{array}$ & 3.90 & 0.937 \\
\hline 3. & $\begin{array}{l}\text { Stakeholder involvement in budget preparation influences } \\
\text { performance of research projects in public Universities }\end{array}$ & $\begin{array}{l}17 \\
(6.9 \%)\end{array}$ & $\begin{array}{l}7 \\
(2.8 \%) \\
\end{array}$ & $\begin{array}{l}31 \\
(12.5 \%)\end{array}$ & $\begin{array}{l}110 \\
(44.2 \%)\end{array}$ & $\begin{array}{l}85 \\
(33.6 \%) \\
\end{array}$ & 3.94 & 0.899 \\
\hline 4. & $\begin{array}{l}\text { Budget guidelines influence performance of research projects in } \\
\text { public universities }\end{array}$ & $\begin{array}{l}7 \\
(2.8 \%) \\
\end{array}$ & $\begin{array}{l}18 \\
(7.0 \%)\end{array}$ & $\begin{array}{l}25 \\
(9.9 \%) \\
\end{array}$ & $\begin{array}{l}136 \\
(54.9 \%)\end{array}$ & $\begin{array}{l}64 \\
(25.4 \%)\end{array}$ & 3.93 & 0.846 \\
\hline 5. & $\begin{array}{l}\text { Budget controls in place influence performance of research } \\
\text { projects in public universities }\end{array}$ & $\begin{array}{l}11 \\
(4.2 \%)\end{array}$ & $\begin{array}{l}21 \\
(8.5 \%)\end{array}$ & $\begin{array}{l}18 \\
(7.0 \%) \\
\end{array}$ & $\begin{array}{l}108 \\
(43.7 \%)\end{array}$ & $\begin{array}{l}92 \\
(36.6 \%) \\
\end{array}$ & 4.00 & 0.948 \\
\hline \multicolumn{7}{|c|}{ Composite Mean and Standard deviation } & 3.93 & 0.74737 \\
\hline
\end{tabular}


The first statement, budget reviews influence performance of research projects in public universities. Out of 250 participants; 109 (43.7\%) agreed, 71 (28.2\%) strongly agreed, $49(19.7 \%)$ neutral, $14(5.6 \%)$ disagreed and 7 (2.8\%) strongly disagreed. This line item has a mean score of 3.89 and standard deviation of 0.871 . The mean score is lower than composite mean of 3.93 and the standard deviation is higher than the standard deviation of 0.747 . This infers that this line item positively influences performance of research projects in public universities.

The second statement, compliance with budgets influence performance of research projects in public universities. Out of 250 respondents, 118 (47.2\%) agreed, 73 (29.2\%) strongly agreed, $31(12.5 \%)$ neutral, 17 (6.9\%) disagreed while $11(4.2 \%)$ strongly disagreed. This line item had an average mean of 3.9 and standard deviation of 0.937 being lower than composite mean of 3.93 and standard deviation higher at 0.871 . This implies that line item positively influences performance of research projects in public universities.

The third statement, stakeholder involvement in budget preparation influences performance of research projects in public Universities. Out of 250 respondents, 110 (44.2\%) agreed, 85 (33.6\%) strongly agreed, 31 (12.5\%) neutral, 17 (6.9\%) strongly disagreed while 7 (2.8\%) disagree. This line item had a mean of 3.94 and standard deviation of 0.899 being was greater than composite mean of 3.93 and standard deviation of 0.747 . This infers that line item positively influences performance of research projects in public universities.

The fourth statement, budget guidelines influence performance of research projects in public universities. Out of 250 participants, $136(54.9 \%)$ agreed, $64(25.4 \%)$ strongly agreed, $25(9.9 \%)$ neutral, 18 (7\%) disagreed while $7(2.8 \%)$ strongly disagreed. This line item had an average mean of 3.93 and standard deviation of 0.846 which is equal to composite mean of 3.93 and standard deviation of 0.747 . This implies that this line item positively influences performance of research projects in public universities. This is supported by survey studies by Ambetsa, 2004 on budgeting control practices at Wilson Airport, showed that the shortfalls experienced were lack participation from staff in budget preparation, budget evaluation deficiencies, and a general lack of support from management. Further, it was determined that the airline use and operate budgets to for performance planning and evaluation. Most organizations plan using budgets in a formally and systematically, others plan informally. The issue that arises here is not if organizations formulate a budget but how to do it efficiently.

The fifth statement, budget controls in place influence performance of research projects in public universities. 108 (43.7\%) agreed, $92(36.6 \%)$ strongly agreed, 21 (8.5\%) disagreed, 18 (7\%) neutral while 11 (4.2\%) strongly disagreed. This line item had an average mean of 4.0 and standard deviation of 0.948 being greater than composite mean of 3.93 and standard deviation of 0.747 implying that this line item positively influences performance of research projects in public universities. This is supported by studies conducted by Adongo and Jagongo, 2013 who noted that budgetary control in Kenya a key part in financial performance of government institutions.

Further, KII ascertain that "a budget is key to positively influence performance of research projects in public universities. Budget cuts have been blamed for poor performance of research projects but universities have come up with innovative ways of getting funds through proposal writing and receiving research grants to enhance performance of research projects in public universities".

\section{B. Correlation Analysis}

A correlation analysis was conducted to ascertain the degree and nature of the interaction between budgets and performance of research projects. Outcomes are shown in Table III.

TABLE III: CORRELATION OF BUDGETS ON PERFORMANCE OF RESEARCH PROJECTS IN PUBLIC UNIVERSITIES

\begin{tabular}{llll}
\hline \hline \multirow{2}{*}{ Variables } & \multicolumn{2}{c}{$\begin{array}{l}\text { Performance } \\
\text { of research } \\
\text { projects }\end{array}$} & $\begin{array}{l}\text { Utilization } \\
\text { of budget }\end{array}$ \\
\hline $\begin{array}{l}\text { Performance of } \\
\text { research projects in } \\
\text { public universities }\end{array}$ & $\begin{array}{l}\text { Pearson } \\
\text { Correlation }\end{array}$ & 1 & \\
\cline { 2 - 4 } & Sig. (2-tailed) & & \\
\hline \multirow{2}{*}{ Budget } & $\begin{array}{l}\text { Pearson } \\
\text { Correlation }\end{array}$ & 250 & $0.890^{* *}$ \\
\cline { 2 - 4 } & Sig. (2-tailed) & 0.000 & 1 \\
\cline { 2 - 3 } & $\mathrm{n}$ & 250 & 250 \\
\hline \hline
\end{tabular}

**. Correlation is significant at the 0.01 level (2-tailed).

There exists a strong positive correlation of $(0.89)$ between budget and performance of research projects in public universities in Kenya. This relationship is significant statistically.

\section{Regression Analysis}

A regression analysis was conducted to in order to establish the influence of utilization of budgets on performance of research projects. Data collected were converted to continuous data by summation to introduce the score.

TABLE IV: MODEL SUMMARY FOR REgRESSION OF BUDGETS ON PERFORMANCE OF RESEARCH PROJECTS IN PUBLIC UNIVERSITIES

\begin{tabular}{lllll}
\hline \hline Model & $\mathrm{R}$ & $\mathrm{R}$ Square & $\begin{array}{l}\text { Adjusted R } \\
\text { Square }\end{array}$ & $\begin{array}{l}\text { Std. Error of the } \\
\text { Estimate }\end{array}$ \\
\hline 1 & $0.890^{\mathrm{a}}$ & 0.792 & 0.789 & 0.14894 \\
\hline a. Predictors: (Constant), budget & & \\
\hline \hline
\end{tabular}

The relationship between budget and performance of research projects in public universities in Kenya explains $79.2 \%$ of all the variations. Other factors not in the model accounts for $20.9 \%$ of all the variation performance of research projects.

TABLE V: ANOVA ON BUDGETS ON PERFORMANCE OF RESEARCH PROJECTS IN PUBLIC UNIVERSITIES

\begin{tabular}{|c|c|c|c|c|c|c|}
\hline & del & $\begin{array}{l}\text { Sum of } \\
\text { Squares }\end{array}$ & Df & $\begin{array}{l}\text { Mean } \\
\text { Square }\end{array}$ & $\mathrm{F}$ & Sig. \\
\hline \multirow{3}{*}{1} & Regression & 5.914 & 1 & 5.914 & 266.564 & $0.000^{\mathrm{b}}$ \\
\hline & Residual & 5.456 & 248 & 0.022 & & \\
\hline & Total & 11.370 & 249 & & & \\
\hline
\end{tabular}

a. Dependent Variable: performance of research projects in public universities in Kenya

b. Predictors: (Constant), utilization of budget

There exists a significant linear association between budget and performance of research projects in public universities in Kenya. 
TABLE VI: COEFFICIENTSA ON BUDGETS ON PERFORMANCE OF RESEARCH PROJECTS IN PUBLIC UNIVERSITIES

\begin{tabular}{llllll}
\hline \hline \multirow{2}{*}{ Model } & \multicolumn{2}{l}{$\begin{array}{l}\text { Unstandardized } \\
\text { Coefficients }\end{array}$} & $\begin{array}{l}\text { Standardized } \\
\text { Coefficients }\end{array}$ & \multirow{2}{*}{ S } & \multirow{2}{*}{ Sig. } \\
\cline { 2 - 5 } & $\mathrm{B}$ & Std. Error & Beta & 4.301 & 0.000 \\
\hline \multirow{2}{*}{1 (Constant) } & 0.396 & 0.092 & & 16.327 & 0.000 \\
\cline { 2 - 4 } & Budget & 0.386 & 0.024 & 0.890 & \\
\hline
\end{tabular}

From the table it can be seen that a budget has a significant statistical influence on performance of research projects in public universities in Kenya since it has a $p$ value of lower than 0.05 .

The resultant model is given as

$$
y_{i}=0.396+0.386 x_{1}
$$

For every change in budget, performance of research projects in public universities in Kenya increases by $38.6 \%$ keeping other factors constant.

$\mathrm{H}_{0}$ : "budget has no significant influences performance of research projects in public universities in Kenya"

The findings suggest that there was a positive statistical influence on utilization of logical framework on performance of research projects in public universities. This is supported by the fact the $p$ value test statistic is less than 0.05 . As a result, the null hypothesis was rejected.

\section{Discussions}

There exists a significant relationship between utilization of budget and performance of research projects in public universities. A strong positive correlation coefficient of 0.89 . The indicators used here, budget reviews, budget compliance, budget guidelines and budget controls. There is positive strong relationship (0.89) between utilization of budget and performance of research projects in public universities in Kenya. This relationship is significantly statistic.

The relationship between utilization of budget and performance of research projects in public universities in Kenya explains $79.2 \%$ of all the variations. Other factors not in the model accounts for $20.9 \%$ of all the variation performance of research projects since it has a $p$ value of lower than 0.05 . The $\mathrm{p}$ value test statistic is lower than 0.05 . This infers that the null hypothesis one which states "budgets approach has no significant influence on performance of research projects in public universities" is rejected.

\section{CONCLUSIONS}

Budgets are tools used to decide the way in which resources are distributed and managed. The aim a budget is limited to expenditure on money, maximizing savings, and capping expenditures. Budget implementation requires advance action for programs which are progressed within the limits of the end of the means available and budget. Effective implementation of budgets is frequently evaluated by addressing variances between budgeted items and the actual performance.
In this regard, the study revealed that utilization of budgets positively influencing performance of research projects in public universities. In this view, Ministry of Education, and the National Treasury should priorities budgeting in order to strengthen the institutions capacity; thereby, improve performance of research projects in public universities. Budget cuts and 'virements' have been credited to under performance of research projects. Therefore, universities are encouraged to be innovative and look for alternative sources of funding so as to enhance performance of research projects in public universities. Public universities should come up with innovative ways of generating funds so as to counter government budget cuts. The study focused on public universities only. Further studies should be conducted in other parastatals. This gap should be explored in similar studies in the future.

\section{REFERENCES}

Adongo, K. \& Jagongo, A. (2013). Budgetary Control as a Measure of Financial Performance of State Corporations in Kenya. International Journal of Accounting and Taxation.

Ambetsa W.O.A (2004), Survey of the Budgeting Practices by Commercial Airlines Operating at Wilson Airport, Unpublished MBA Thesis, University of Nairobi, School of Business.

Amboga, J. G. (2009). Adoption of the balanced scorecard in strategy implementation at the Kenya wildlife service (Doctoral dissertation, school of business, university of Nairobi).

Amonoo-Neizer, E. H. (2008). Universities in Africa-the need for adaptation, transformational and revitalization. Higher Education. Policy, 11:301-309. Applications. New York: Braziller. Aldehayyat, J. S., Al Khattab, A. A. (2013). Strategic planning and organizational effectiveness in Jordanian hotels. International Journal of Business and Management.

Amonoo-Neizer, Eugene H., (1998). Universities in Africa: the need for adaptation, transformation, reformation and revitalization. Higher Education Policy. P. 11

Armstrong, M. (2005). A handbook of human resource management practice. $\left(9^{\text {th }}\right.$ Ed.). London: Kogan Page.

Blair, R. and Jordan, J. (1994). Staff loss and retention at selected African universities: A synthesis Report, after Technical Note No.18, Human resources and poverty Division, technical department, Africa region, the World Bank, Washington D.C.

Carolyn M. Callahan, (2007). An Examination of the Effects of Budgetary Control on Performance: Evidence from the Cities. AAA 2008 MAS Meeting Paper.

Fisher, A., Laing, J., \&amp; Stroker, J. (2003). Operation Research Design in Sampling.Washington, DC: Population Council.

Frucot, V., Shearon, W.T. (2001), "Budgetary participation, locus of control, and Mexican managerial performance and job satisfaction", The Accounting Review, Vol. 66 No.1, pp.89-99.

Gachithi, E. (2010). The Challenges of budget implementation in Public Institutions: A case study of University of Nairobi. Unpublished MBA Project. University of Nairobi

GoK, (2005). Sensitization on Performance Contracts in the Public Sector. Unpublished Training Manual. Nairobi: Government printer.

Hansen, D. R and Mowen, M.M (2005). Environmental Cost Management, Management Accounting, Thomson-South-Western, Mason, OH, pp. 490-526

Horngren C. T. (2000). Cost Accounting, a Managerial Emphasis. $4^{\text {th }}$ edition, Prentice Hall India, New Delhi.

Kariuki (2010). Budgeting: A fundamental management tool. Kasneb Newsline Volume 1, page 4)

Larsson, Kjell, (1999). "The Impact of EU Accession on Budgeting, Control and Audit" in SIGMA 6.

Latham G. P and Locke E. A., (2002). Building a practically useful theory of goal setting and task motivation. American psychologist 57, 705717.

Lucey, T. (2004). Management Accounting. Bedford Row, London: Thomson

Mbugua, S. G. (2013). The Relationship between Budgeting Practices and Performance of Organizations in The Water Sector in Kenya (Doctoral dissertation, University of Nairobi). 
MelekEker (2007). The impact of budget participation on managerial performance via organizational commitment. Unpublished PHD Thesis Akdeniz University Faculty of Economics.

Mugenda, O. M., \& Mugenda, A. G. (2003). Research Methods: Quantitative and Qualitative Approach. Nairobi: Acts Press.

Mullins, L. (1999). Management and organizational behavior. ( $5^{\text {th }} \mathrm{Ed}$.). London: Financial Times-Prentice Hall

Mwangi, C. M. (2014). Assessment of Effects of Budgetary Planning Tools on the Financial Performance of Registered Public Service Vehicle Companies. A Case of Kisii County Kenya (Doctoral dissertation, Kisii University)

Olusola, O. (2007). Emerging Challenges Facing African Higher Education Institutions, Paper presented at the Norwegian Centre for International Cooperation, International Conference on "Higher education in development", 18 - 20 October, 2007, Maputo, Mozambique.

Orodho and Kombo (2003), Research methods, published by Masola publishers, printed in Nairobi.

Orodho, A.J. (2003). Essentials of Educational and Social Science Research Methods. Mazola Publishers, Nairobi.

Premchand A (2000). Control of Public Money. The Fiscal Machinery in Developing Countries, Oxford. Oxford University Press. Shelfmark: SPIS.336.091724

Saint, W. W. (2002). Universities in Africa: Strategies for stabilization Revitalization) the World Bank: Washington D.C.

Saleemi, N.A. (2006). Principles and practice of management simplified. (Rev. Ed.). Nairobi: ACME Press (Kenya) Limited.

Tashakkori, A. \& Teddlie, C. (2003). Handbook of Mixed Methods in Social \& Behavioral Research. Thousand Oaks: Sage

The Universities Act, (2012). No. 42 of 2012

Werner, P. (2004). Reasoned Action and Planned Behavior, in S.J. Peterson \& T.S. Bredow (eds), Middle Range Theories: Application to Nursing Research (125-147). Philadelphia: Lippincott Williams \& Wilkins

William, L. C., John, W. S. Jr., Don, V. W., \& Frank, Q. F. (2005). The role of goal orientation on negative emotions and goal setting when initial performance falls short of one's performance goal. Human Performance, 18, 55-80.

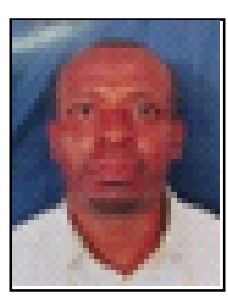

Hamisi Jitta Mwaguni $\mathrm{PhD}$ scholar. Born in Mombasa, Kenya. Has a Masters of Arts in Project Planning and Management from University of Nairobi, Kenya 2012 and a Bachelor of Arts Degree in Development Studies from Kampala International University, Uganda 2009. Expert in research and Monitoring and Evaluation.

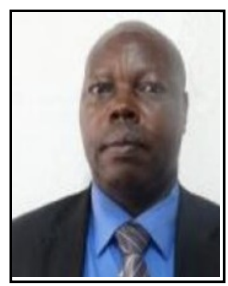

Dr. John Mbugua is a Senior Lecturer, University of Nairobi, Kenya. He has a Doctor of Philosophy (Distance Education), Master of Education, and Bachelor of Education (Arts).

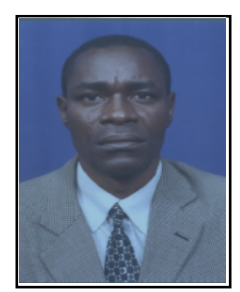

Prof. Charles Rambo is an Associate Professor, University of Nairobi, Kenya. He has a PhD degree in Financing Distance Education, MBA Degree in Finance of Newport University - California, and a BBA Degree with a major in finance and a minor in accounting of Newport University - California USA. 